\title{
Financial Management and E-Commerce Training in Steps to Increase Revenue at Abah Ukar Blacksmith in Tasikmalaya
}

\author{
Gina Nuraini and Grida Saktian Laksito*
}

Research Collaboration Community, Bandung, Indonesia

Corresponding author email: gridasaktianlaksito@gmail.com

\begin{abstract}
The implementation of financial management and marketing training through E-commerce is a form of community service, with the aim of helping SMEs Blacksmith Abah Ukar to increase revenue and product sales so that Blacksmith Abah Ukar can survive in today's business competition. The era that uses technology today requires all small industry players to improve their abilities in the field of communication and information technology, currently internet-based technology creates a business environment that is no longer concerned with time and distance. This method of community service activity has a background problem because the products made by the blacksmith Abah Ukar are still sold conventionally and have not made good use of online sales using an ecommerce platform and the blacksmith Abah Ukar has not kept a record of their production so that the income earned cannot be well predicted. The results of the research carried out were able to innovate marketing which was originally conventional into marketing that utilizes technological developments, namely by doing electronic marketing or also called E-commerce.
\end{abstract}

Keywords: Training, e-commerce, financial management

\section{Introduction}

The rapid development of internet technology gave rise to the concept and practice of electronic commerce such as e-commerce which has become a common phenomenon in today's world. The internetbased economic structure and information groups are a new business reality, because organizations and individuals enjoy the convenience of purchasing commodities and services from abroad, but most developing countries are still far from experiencing this reality due to many factors that hinder the development of e-commerce (Alyoubi, 2015; Aditantri et al., 2021). In this case, e-commerce is one of the easiest alternatives to support someone in entrepreneurship (Aribawa, 2016; Luthfihadi and Dhewanto, (2013). Many applications are offered as stalls to oversee individual independent businesses for people who want to be entrepreneurs and do not look at one's age or work background so that they can support competition to a global level.

Material regarding the description of information technology in the form of e-commerce that can integrate with social media is also very much needed because it makes people more aware to continue to 
develop themselves in terms of science and information (Saleh and Dewi, 2020). Along with the development of Information Technology in the current 4.0 revolution era, it is possible to take seriously the exploration of the potential of human resources both at the level of entrepreneurial independence, thus demanding technology to be able to follow the level of community needs for the problems that have occurred so far (Taufiq and Fitri, 2020, Sambas et al., 2019; Risnandar et al., 2019)

Business transaction activities using e-commerce make it very easy for the community where important information and the latest updates that are presented can be very easily and quickly obtained by information consumers (Rahayu and Day, 2017). In this case, the community must also be able to follow the rhythm of the times where the era of modernization is developing very rapidly, especially in terms of information technology so that people must have sufficient knowledge and insight to coexist with an allelectronic era like today (Raharja et al., 2019).

Business transaction activities using e-commerce are very easy for the community where important information and the latest updates that are presented can be very easily and quickly obtained by information consumers. In this case, the community must also be able to follow the rhythm of the times where the era of modernization is developing very rapidly, especially in terms of information technology so that people must have sufficient knowledge and insight to coexist with an all-electronic era like today.

According to MacGregor and Kartiwi (2020), Along with the development of the current business world, e-commerce is a necessity to improve and win business competition and product sales. Ecommerce seems to have a strong appeal so that many individuals or organizations are interested in running a business

According to Chakim et al. (2021), financial planning involves setting goals, valuing assets and resources, estimating future financial needs and making plans to achieve monetary goals and suggesting in one systematic approach to achieve effective management performance is financial planning, budgeting and that the sustainability of any project lies in managing effective finance right from the implementation stage to the post-implementation stage. It is important to lay out and plan our budget for the amount of money received (Karanja 2014).

According to Mir and Sutiyono (2013), Financial Management is a combination of science and art that discusses, examines and analyzes how a financial manager uses all company resources to seek funds, manage funds and distribute funds with the aim of providing profit or prosperity for shareholders and business sustainability for the company.

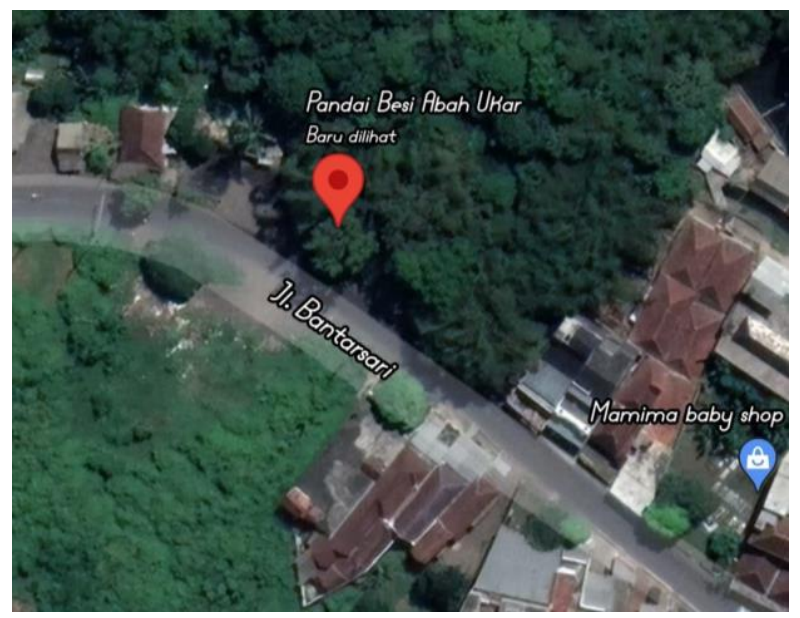

Figure 1. Map Location Blacksmith Abah Ukar

Based on research conducted by Saridakis et al. (2017) mentioned that the increase in performance was not significantly different among SMEs that were at the E-commerce development stage. In 
summary, business performance appears to improve as entrepreneurial organizations adopt information technology to facilitate greater market communication and increased exposure to online shoppers. Then the research was carried out by Purba et al. (2021), the research shows that digital marketing has a significant effect on business continuity, then e-commerce has a significant effect on business continuity and digital marketing has a significant effect on financial performance. The use of digital marketing is done to increase customer awareness. Marketplace as a manifestation of e-commerce is used as an innovation or change in sales methods. The map location blacksmith Abah Ukar can be seem In Figure 1.

The purpose of this community service is to help SMEs blacksmith Abah Ukar increase marketing widely based on digital marketing by utilizing e-commerce platforms, increase the income received, and SMEs can also estimate the profits and losses in one production that has been done by SMEs. the. Some of the things the team did in this service activity were to provide socialization of understanding how to understand digital marketing-based marketing by utilizing an e-commerce platform and then providing assistance to SMEs so that they could carry out bookkeeping, specifically related to their financial entry and exit.

\section{Materials and Methods}

\subsection{Materials}

The implementation of the service activity will take place on May 24, 2021 at Jl.Bantarsari, Kec. Bungursari, Kab. Tasikmalaya, Jawa Barat 46151. The location Blacksmith Ukar in Tasikmalaya can be seen in Figure 2.

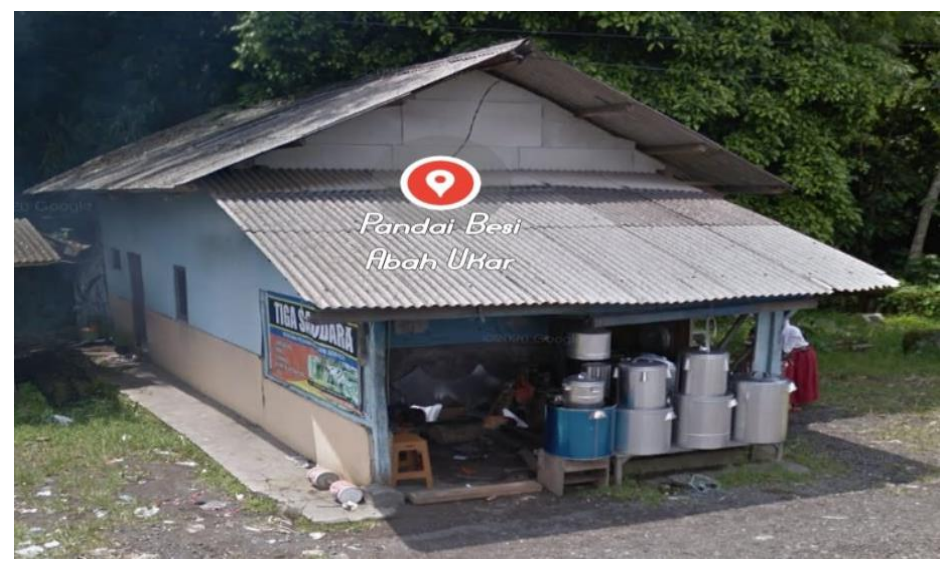

Figure 2 Location Blacksmith Ukar in Tasikmalaya

\subsection{Methods}

The methods used in the implementation of community service activities are field analysis, socialization of activities, and training which includes:

- Field Analysis

- This activity is carried out as the beginning of the activity with the aim of obtaining a description of the condition of the targeted UKM; namely by holding a meeting with the owner of the 3rd generation blacksmith SME owner Abah Ukar, namely Mr. Aa Sumarna.

- Socialization of Activities 
- At this stage, the service team will provide and explain the service plan that will be carried out so that time and various technical needs can be arranged in connection with the overall implementation of training for the owner of the blacksmith UKM Abah Ukar.

- Training

- Digital marketing-based marketing training utilizes the e-commerce platform by helping SME owners understand some of the facilities and advantages that can be used as a product marketing tool and then given ways for partners to have accounts and can operate E-commerce in the Tokopedia, Bukalapak, Lazzada and Shopee applications. Provide an explanation of the importance of making international standard products, so that the products produced can compete with products in the international market share, then provide an explanation of the brand on the product so that consumers can easily remember and distinguish it from other products. Then the last one is giving an explanation about the importance of bookkeeping in a business unit so that partners can find out whether the business is making a profit or loss and can estimate the profits generated in one production.

\section{Results and Discussion}

This Community Service (PKM) activity was held on Jl. Bantarsari, Kec. Bungursari, Kab. Tasikmalaya, West Java 4615 This training method aims to provide knowledge about digital marketingbased marketing by utilizing e-commerce platforms so that the product marketing area becomes wider then training on financial management such as making bookkeeping so that owners know what production they are doing within a certain period of time. time to get a suitable profit or even become a loss. The implementation of this counseling is fully supported by the owner of the SME Pandai Basi Abah Ukar by giving permission to hold training for the SMEs he owns. The process of working on products at the Blacksmith's Place Abah Ukar can be seen in Figure 3.
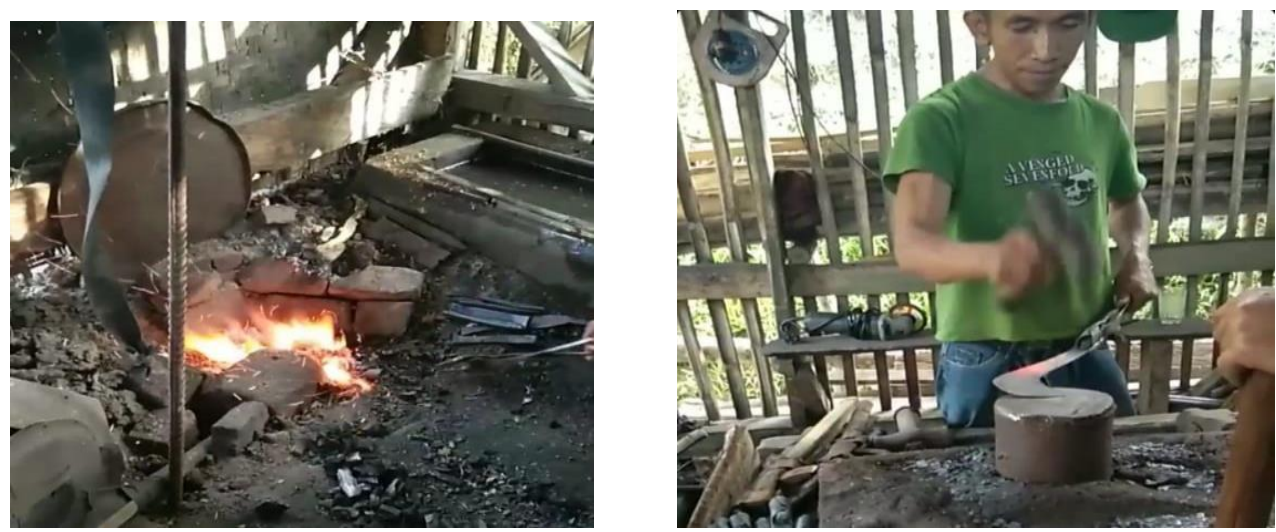

Figure 3 The Process of Working on Products at the Blacksmith's Place Abah Ukar

This service will provide several activities to overcome what are the problems of SME owners, namely by providing training and assistance. The training carried out is related to how to get a simple product brand, determine packaging, good bookkeeping, and obtain an account in an e-commerce application. This training is given with the aim of opening up the insight of SME owners that every good product cannot be separated from giving a good brand to the product produced.

The resulting product must be packaged in an attractive, good and safe manner, this is done so that the goods produced are not easily damaged even though they are in the packaging. In addition to the training mentioned above, the community program team provides marketing training based on digital marketing 
by utilizing the e-commerce platform where this training aims to introduce and at the same time train SME owners to use digital marketing by utilizing e-commerce platforms in marketing their products. This service also provides bookkeeping training to SME owners because it is best if a business has financial management through good bookkeeping training, a business that has been pioneered with great difficulty certainly does not want its business to be destroyed because it does not have good financial management in the business itself..

Good financial management will lead to the achievement of the goals of a production itself, and vice versa bad financial management will lead to the destruction of even a large business. The last training is training related to account acquisition from e-commerce applications on the Tokopedia and Lazada applications. As we all know, although technology has many negative impacts, there are also many benefits that can be taken from technological developments, one of which is that it can be used as a means of promotion that does not drain the finances of a business, especially small industrial businesses or home industries. This training teaches SME Owners how SME Owners can register and obtain an account on an e-commerce application on an online application.

This service not only provides training but also provides assistance to the SME Owner of the Abah Ukur Blacksmith SME. This assistance is given to strengthen what has been received by SME owners in training activities. SME owners are assisted in marketing products on e-commerce applications, this is done because SME owners feel the need to be given assistance in operating e-commerce marketing. This assistance is also given to SME owners for SME owners to record transaction activities for selling blacksmith products such as machetes, knives, and so on, so far, SME owners do not have good bookkeeping so it is impossible to know for sure the profits that have been obtained after deducting production operational costs.

By implementing the SME Ownership program, SME Owners can be able to solve what has been the problem so far, SME owners now have a simple brand which later the brand cannot be followed by other industries, and this can provide protection for the business owned by SME owners. . In addition to the current brand, SME owners also have good and attractive packaging so that they are attractive to new consumers, where initially SME owners only packaged their products with ordinary wood without any interesting carvings, now SME owners have added better packaging to their products with wood carving in the packaging of the blacksmith's product.

With the addition of this packaging, it is hoped that the product will appeal to new consumers. In addition to having resolved brand and product packaging issues, now SME owners have also overcome marketing problems that previously conventionally have now marketed by utilizing their products on online-based e-commerce applications, this is a new means for SME owners to promote to the general public and broad, not limited by distance.

\section{Conclussion}

The knowledge of participants in this case are business actors and residents in Cisewu Village from RT 001-005/RW 002, Cisewu District, Garut Regency regarding digital marketing-based marketing before the training conducted by the team, the majority of participants were in the category of not understanding. After the training activities were carried out and the material presentation was delivered, the MSME training succeeded in providing participants with increasing knowledge about digital business.

\section{References}

Aditantri, R., Mahliza, F., \& Wibisono, A. D. (2021). Urban Planning and E-Commerce: Understanding the Impact During Pandemic Covid-19 in Jakarta. International Journal of Business, Economics, and Social Development, 2(3), 135-142. 
Alyoubi, A. A. (2015). E-Commerce in Developing Countries and How to Develop Them during the Introduction of Modern Systems. Procedia Computer Science, 65(1), 479-83.

Aribawa, D. (2016). E-commerce strategic business environment analysis in Indonesia. International Journal of Economics and Financial Issues, 6(6S), 130-134.

Chakim, N. R., Indradewa, R., Yanuar, T., \& Syah, R. (2021). Financial Planning: Applications to Business Startups" Jamu Partnership" in Indonesia. 8(2), 483-487.

Karanja, G. M. (2014). Influence of Management Practices on Sustainability of Youth Income Generating Projects in Kangema District, Murang'a County, Kenya. International Journal of Education and Research 2(2), 1-12.

Luthfihadi, M., \& Dhewanto, W. (2013). Technology Acceptance of E-commerce in Indonesia. International Journal of Engineering Innovation and Management, 3(1), 9-18.

MacGregor, R. C., \& Kartiwi, M. (2010). Perception of barriers to e-commerce adoption in SMEs in a developed and developing country: a comparison between Australia and Indonesia. Journal of Electronic Commerce in Organizations (JECO), 8(1), 61-82.

Mir, M., \& Sutiyono, W. (2013). Public sector financial management reform: A case study of local government agencies in Indonesia. Australasian Accounting, Business and Finance Journal, 7(4), 97-117.

Purba, M., Simanjutak, D., Malau, Y., Sholihat, W., \& Ahmadi, E. (2021). The effect of digital marketing and ecommerce on financial performance and business sustaina-bility of MSMEs during COVID-19 pandemic in Indonesia. International Journal of Data and Network Science, 5(3), 275-282.

Raharja, S. U. J., Kostini, N., Muhyi, H. A., \& Rivani. (2019). Utilisation analysis and increasing strategy: ecommerce use of SMEs in Bandung, Indonesia. International Journal of Trade and Global Markets, 12(3-4), 287-299.

Rahayu, R., \& Day, J. (2017). E-commerce adoption by SMEs in developing countries: evidence from Indonesia. Eurasian Business Review, 7(1), 25-41.

Risnandar, M. A., Sambas, A., \& Ula, S. (2019). PKM Pelatihan Perakitan Elektronika Sebagai Bekal Keterampilan Generasi Milenial Di Kota Tasikmalaya. MARTABE: Jurnal Pengabdian Masyarakat, 2(2), 78-84.

Saleh, M. P. A. Q., \& Dewi, S. (2020). Design of Enterprise Information System Architecture with Oracle Architecture Development Process (OADP) Case Study in Vocational High Schools. International Journal of Quantitative Research and Modeling, 1(4), 217-228.

Sambas, A., Gundara, G., \& Ula, S. (2019). Pelatihan Robotika Berbasis Android Untuk Menumbuhkan Inovasi dan Kreativitas di SMP 11 Bandung. Martabe: Jurnal Pengabdian Kepada Masyarakat, 2(1), 8-12.

Saridakis, G., Lai, Y., Mohammed, A. M., \& Hansen, J. M. (2018). Industry characteristics, stages of E-commerce communications, and entrepreneurs and SMEs revenue growth. Technological Forecasting and Social Change, 128, 56-66.

Taufiq, M., TAG, N. L. B., Fitri, S., \& Rubiani, H. R. H. (2020). Pelatihan Manajemen Potensi Berprestasi Di Era Revolusi Industri 4.0 Untuk Para Guru Dan Siswa Di Kabupaten Pangandaran. Monsu'ani Tano Jurnal Pengabdian Masyarakat, 3(1), 1-12 